\section{Scholars Journal of Arts, Humanities and Social Sciences}

Sch. J. Arts Humanit. Soc. Sci. 2017; 5(7B):716-720

(C)Scholars Academic and Scientific Publishers (SAS Publishers)

(An International Publisher for Academic and Scientific Resources)

\title{
The Behavior of Apparatus and Cultural Organization in Provision of Public Service in District Level Hesty Tambajong ${ }^{1}$, Zulfan Nahruddin ${ }^{2}$ \\ ${ }^{1}$ Faculty of Social and Political Sciences, Musamus University of Merauke, Indonesia \\ ${ }^{2}$ Faculty of Social and Political Sciences, Muhammadiyah University of Makassar, Indonesia
}

\author{
*Corresponding Author: \\ Hesty Tambajong \\ Email: hestytambajong@yahoo.co.id
}

\begin{abstract}
This study aims to determine the behavior of district officials in the delivery of public services and know the culture of a growing organization in the district office in order to give service in society. Meanwhile at the end of this study, it can provide insight into the raising behavior from organization culture. This study used a qualitative approach, the sampling is purposive data sources on the apparatus districts and snowball on society service recipients in Tamalanrea district. The results showed that reflected behavioral aspects of the experience and discipline of apparatus, transparency and rules observance would make the bureaucracy becomes stiff but it aims to prevent irregularities and chaos in the administration service. Besides that the openness have become important factors in the process of public services, the information provided openly necessary in order to attempt to obtain a compensation. It does not occur to the apparatus meanwhile the service can be sincere. Then the findings of this study indicate that the culture that is built on the ideals, values that exist within the organization over time will form the professional behavioral apparatus.
\end{abstract}

Keywords: Behavior, Apparatus, Organizational Culture, Public Service.

\section{INTRODUCTION}

Professional bureaucracy issues are still coveted by society. It happens because many people who have the hope that the bureaucracy is able to show maximum performance, look professional in carrying out public services and be able to promote the interests of society and not under pressure of certain political groups.

One indication of the poor quality of the regional state apparatus is a violation of discipline. It is mostly done by the regional state apparatus. Development is actively carried out in Indonesia often face many obstacles and problems are quite complex. This can lead to lack of disorderly in the life of the nation. Increased discipline within the state apparatus is one attempt to address the lack of order [1].

Many of the problems associated with public services, including the uncertainty of the time, cost, and how the provision of services to the public and others that make people do not get the satisfaction of making the poor service quality [2]. One of the major challenges facing the government is the ability to implement activities effectively and efficiently, because during this time the government officials convoluted synonymous with performance -belit filled with corruption and there is no definite standard Rusnani [3].

Quality services often find it difficult to be achieved because the officers do not always understand how to provide good service, this is the case because of the poor professional skills of officers viewed from an educational background and work ethic of human resources personnel and authority possessed by officers concerned. Increasingly critical public to demand quality of service shows the character of our present society that has independent attitude, open and capable of democracy [4].

District as a public service provider has a fundamental duty to help the Regent in governance and community development in districts. It increases the effectiveness of public services within the framework of good governance. Things traced in this study is the behavior and culture in the district government officials gave the public service in districts of Tamalanrea Makassar. Investigated the influence of organizational behavior which is owned by individuals, groups and structures of the behavior in the organization, which aims to apply this kind of science to improve the effectiveness of an organization [5]. While the organizational culture in the public sector more emphasis on public services as influential in creating a 
good public service. One of the organizational culture in private competence of officers [6]. Internal factors that influence the behavior of the organization can be seen from intenal factors that influence individual behavior and group behavior in organizations [7].

The importance of the knowledge of the behavior and organizational culture that is in the Office of districts will be the factors that affect the performance of public services in district area it is in line with the opinions Beheshtifar and Zare [8] stated that the support organization is one of the important factors that may affect the behavior of individual work officers. Therefore, these two aspects become relevant in this study to explore together the two aspects of behavior and culture can be a powerful image to spur better organizational performance. Past research on the behavior and culture of the organization is done by Nurwati [9] showed improvement in organizational culture play a role in improving the working behavior. An organizational culture that is realized by working innovatively, dare to take risks and result oriented able to improve workplace behavior that is by improving employment initiative power.

Then the results Sjafari [10], show that the leadership behavior is very influential on the climate establishment of the organization at the District Office. Organizational climate that has a very real correlation with aspects of the role and personality of each officer, both officers at lower levels or leadership. Further research Purnamasari [11] emphasizes organizational behavior as a function of the individual interaction with the environment. Results The study found that the behavior of the organization in the District government offices still need to be improved in order to create orderly administration services with effective and efficient.

In this research focuses on aspects of behavior and organizational culture that aims to understand the behavior of the apparatus districts in the provision of public services and know the culture of the organization that developed in the Office districts in efforts to provide services to the district Society Tamalanrea until in the end this research may provide insight into the behavior of the awakened of the culture of the organization.

\section{RESEARCH METHODS}

This study used a qualitative approach, where an explanation of qualitative research According Sugiono [12] is a research method that is based on the philosophy postpositivisme, is used to examine the condition of the object that is natural, (as his opponent is an experiment) where researchers are a key instrument, sample source Data were purposively for Administrative Districts and snowball for beneficiaries, collection techniques by triangulation (combined), data analysis is inductive / qualitative and qualitative research results further emphasize the significance of generalization. The subjects of this study consisted of district Tamalanrea Makasar, Secretary, Head of Public Service, Head of Public Welfare and Society Services in Sub Recipients Tamalanrea number of 7 people. The data collection is done by observation, interview and documentation. Then the data analysis technique that is data reduction, data display, and conclusion drawing / verification.

\section{RESULTS AND DISCUSSION}

\section{The behavior of the District Government Personnel in Service Delivery}

Task districts namely apparatus airport in terms of making service of Identity Card (KTP), inheritance Services / heirs, Building (IMB), information moved and so on. Behavior of the apparatus can be seen from his experience that the process of formation of knowledge or skills about methods of a job because of the involvement of personnel districts in the activities of KTP, IMB and other services will be greatly assisted by the experience, thereby reducing a long time in gave the service only because of the slow work because of the lack of experience.

Work long enough period of work experience is deemed capable of carrying out the work and easily customize tasks and areas of work, as well as to carry out those responsibilities, in other words more often do the same job then someone will continue bertamabah experience. Experience the apparatus is working long hours affect the productivity performance. The tenure of the apparatus is one of the assessments to measure how a person's ability to complete the task, for example, the longer a working apparatus of higher performance because it has experienced hah tasks and issues related to the job.

Based on interviews the researchers did with the speakers in this study, it can be seen that the work experience possessed by the device subdistrict is broad enough to the experiences of its apparatus districts are able to carry out their duties properly either in administration or in service on society. Document management is quite good because the time required buffer find them easily. the archivement was rediscovered easily located on the accuracy in recognizing the archive according to the instructions. But what happens in the management of archives at the Office despite being good but still a simple and still to be improved, for example the low quality of human resources that support the lack of facilities in records management. 
Another thing that is found on the district officials Tamalanrea attitude is very dependent on the personal performance of each apparatus. Honest officers, who provide services to the Society without expecting anything in return in any form will certainly expedite service and uncomplicated it is done until people can obtain satisfaction. Additionally discipline district officials when carrying out work on the job does not charge co-worker who was not his job. All implementation tasks in accordance with its responsibility in their respective areas. Only in certain circumstances the apparatus may switch roles if those services in urgent circumstances.

\section{Attitude responsive service}

Based on the interview can be seen that the services provided apparatus subdistrict Tamalanrea responsive enough of a public response is that services are given quite good and not complicated just that some informants are still not read well the procedures given until the apparatus subdistrict must explain longer again. Officials with the performance of public services in the district can be understood that every public service provided, always must be improved its performance in accordance with the service user wishes for the Society it serves has a different character.

Based on the results the researchers did interviews with several informants, that communications made in implementing the policy of Act No. 25 of 2009 on Public Service in the district office Tamalanrea good enough. Public services such as service cards (KTP) has done fairly well, inheritance Services / heir done quite well, Bangunan (IMB) take a long time, information move is also quite good. Public service is the main goal for the district government in serving the public. So the reform and improvement of service quality become a big hope for the Society. Measured from the aspect of responsiveness, Procedures and the level of satisfaction, the service in the District Tamalanrea judged necessary to be faster in terms of service for making satisfaction services to the society but it still obey the principle and the principle of service in accordance with the rules in the Act No. 25 of 2009 on the Public Service. Additionally important gesture owned apparatus is openness. Openness is meant here, means things - matters relating to the public service shall be informed in the open to be easily identified and understood by the public is requested or not requested. The desire of customers are served honestly. Therefore personnel on duty should provide an explanation as honestly - honestly, what in the rules or norms, do not scare - scare the procedure for tough,

\section{Organizational Culture on aspects Environment and Values}

The work environment is filled by many districts that older people require their culture of respect for elders is still valid in the organizational culture in the District Tamalanrea. But in terms of the job the boss does not need to discriminate against an officer only by the treatment on grounds of age. Many officials of the old age but from the intellectual and emotional side is still very unstable. many officers from the young age but from the intellectual and emotional side has been very stable and mature. Only if outside office hours remain implanted in respect older.

Based on the interview were awakened culture it is customary to always offer interpretations service procedures this happens because of a lack of public awareness. Public awareness is the awareness is intended to prepare all the requirements to perform a service in the district affairs, communication between government officials with the public must support each other in order to achieve the desired objectives, either from the public or government officials themselves.

Constraints faced by public servants in providing services to the public in the form of incomplete administrative requirements for the proposed public or requirements needed not attached. To overcome these obstacles, public services subdistrict give sense to the Society, asking the Society to attach the requested requirements and confront society with the patient, in providing services to the Society sometimes people also make a claim for dissatisfaction with the services obtained therefore patience to always give an explanation with both absolutely necessary in order to keep a satisfactory service to the Society.

\section{Organizational Culture on aspects exemplary}

Based on the results of interviews conducted can be obtained by the understanding that the working environment Tamalanrea District of demands to always disciplined and always memotoring each activity to be undertaken in addition to the good communication also becomes important in this work environment factors. Based on the interview can be obtained picture that values such as mutual respect and respect each officer is maintained within the scope of the district office Tamalanrea which aims to maintain harmonious working environment remains besides foster a sense of familiarity and maintaining professional to be disciplined in the office. Exemplary examples given by the leadership of the subdistrict head against officers in low level.

Based on the results of Interviews conducted can get illustration that there is a leader who can break the ice in certain situation but still professional in working, friendly and respect to each officer. It makes him as a good leader for apparatus district. 
Behavior that is built on the culture of the organization

Behavior apparatus emerged from the research revealed a discipline on the number of officers on the time came to office, in obedience to rules applicable in both the technical and implementation guidance set by the government and disclosure of information services is a form of representative of the organization's leaders. Therefore culture that is built on ideals, values that exist within the organization over time will form the professional behavioral apparatus. For more details can be seen in the following figure.

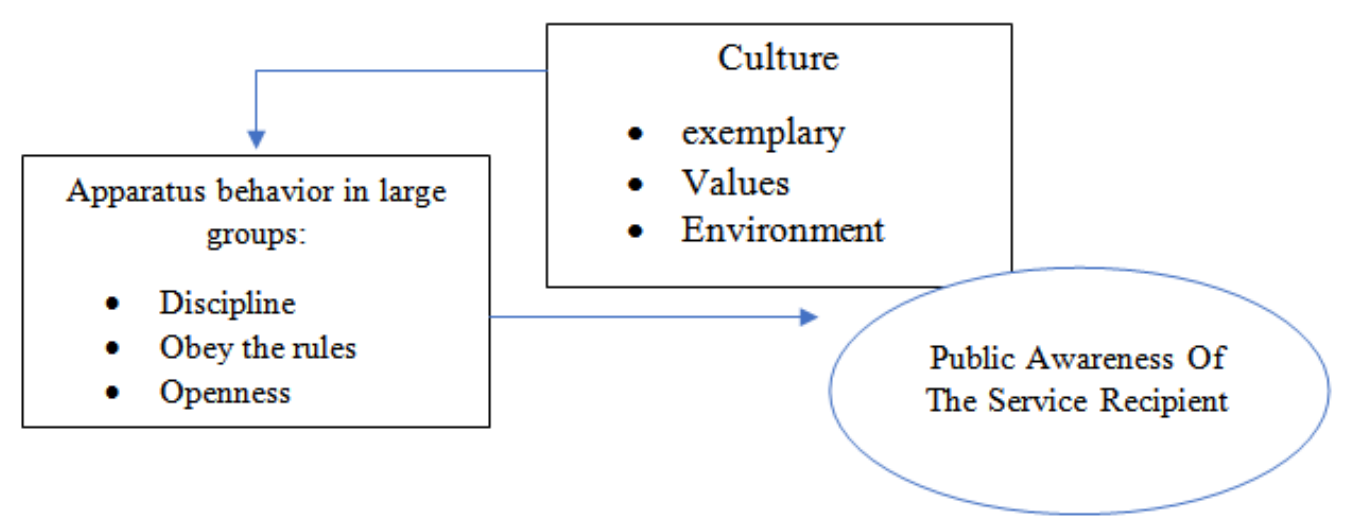

Fig-1: Flow Behavior Perspective built from the culture of the organization

Source: Processed primary data research

Appropriate observations and the results showed a number of interesting things that the discipline of a number of large dominant group in terms of behavior will affect a small group that is not dominant. This condition will affect the small group became submerged by a strong organizational culture that exist within the organization.

Discipline would form a district that professional discipline officers entered the office and finish the job with a good punctuality. Timeliness is intended that exercising their public services can be completed within a predetermined time. This is supported by the ability of authorities to resolve the ministry, and adequate facilities.

Observance of the rules would make the bureaucracy becomes stiff but it aims to prevent irregularities and chaos in the administration of the service. Besides openness have become important factors in the process of public services, the information provided openly necessary in order to attempt to obtain a compensation does not occur to the apparatus until the service can be sincere and Ihlas. In addition, through the open attitude of the apparatus can build public awareness that not adalagi shortcut to mempercapat services through bribes or rewards but it meets all the requirements given that services become easier to be very helpful services are carried out.

\section{CONCLUSION}

Experience and discipline of a number of authorities, obedience to rules applicable in both the technical and implementation guidance set forth by the government, and disclosure of information services is a form of reflection of the organizational culture that has been built. Observance of the rules would make the bureaucracy becomes stiff but it aims to prevent irregularities and chaos in the administration of the service. Besides openness have become important factors in the process of public services, the information provided openly necessary in order to attempt to obtain a compensation does not occur to the apparatus until the service can be sincere and Ihlas. culture that is built is a habit to always give an explanation will sebetulincorrectness service procedures can provide awareness to the society.

\section{REFERENCES}

1. Haydah TN. Kendala dan solusi dalam peningkatan disiplin pegawai negeri sipil daerah (Studi di Badan Kepegawaian Daerah Kabupaten Malang). Jurnal Mahasiswa Fakultas Hukum. 2014 Jan 15; 1(10).

2. Sari N. Pengembangan Kapasitas Kelembagaan Pemerintah Daerah dalam Meningkatkan Kualitas Pelayanan Perizinan Terpadu (Studi pada Kantor Pelayanan dan Perizinan Terpadu Kabupaten Kediri). Jurnal Administrasi Publik. 2014 Apr 20; 2(4):634-40.

3. Rusnani, Sitti. Persepsi Masyarakat Tentang Pelayanan Publik Di Kantor Kelurahan Handil Bakti Kecamatan Palaran Kota Samarinda. Ejournal Administrasi Negara, 2013; Volume 1, No. 2, 365-379.

4. Lendo R. Kinerja aparat desa dalam pelayanan publik di desa wuwuk kecamatan tareran kabupaten 
minahasa selatan (Studi Tentang Pelayanan Surat Keterangan Tidak Mampu). Jurnal Eksekutif. 2015 Oct $4 ; 1(7)$.

5. Robbins, Stephen P. \& Judge, Timothy A. Perilaku Organisasi Edisi ke-12, Jakarta: Salemba Empat. 2008

6. Wahyuni, E., 2015. Pengaruh Budaya Organisasi dan Gaya Kepemimpinan Terhadap Kinerja Pegawai Bagian Keuangan Organisasi Sektor Publik Dengan Motivasi Kerja Sebagai Variabel Intervening (Studi Kasus Pada Pegawai Pemerintah Kota Tasikmalaya). Nominal: Barometer Riset Akuntansi dan Manajemen, 4(1).

7. Hendra H. Totua Ngata dan Konflik (Studi atas Posisi Totua Ngata sebagai Lembaga Adat di Kecamatan Marawola). Antropologi Indonesia. 2014 Jun 27.

8. Zare E. Effect perceived organizational support on employees' attitudes toward work. Science Series Data Report. 2012 Sep; 4(9).

9. Nurwati,. Pengaruh Budaya Organisasi terhadap Perilaku Kerja dan Kinerja Karyawan (studi pada Koperasi Unit Desa di Provinsi Sulawesi Tenggara). JSM (Jurnal Sains Manajemen), (2012); Vol.1, No.1, 41-51.

10. Sjafari, Agus. Analisis Organisasi Melalui Pendekatan Perilaku (Kasus di Kantor Kecamatan Kemayoran Kotamadya Jakarta Pusat). Jurnal Adminsitrasi Publik 2012; Volume 3 No. 1, 1-10.

11. Hanny Purnamasari,. Perilaku Organisasi Dalam Pelayanan Administrasi Kependudukan (Studi Pelayanan Pembuatan Kartu Keluarga (KK) Pada Kantor Kecamatan Lemahabang Kabupaten Karawang). Jurnal Politikom Indonesiana, 2016; Vol.1 No.1, 154-163.

12. Rueping M, Sugiono E, Schoepke FR. Thieme chemistry journal awardees-Where are they now? Asymmetric Brønsted acid catalyzed transfer hydrogenations. Synlett. 2010 Apr;2010(06):85265 . 